\title{
Type I collagen gene suppresses tumor growth and invasion of malignant human glioma cells Kimi Honma ${ }^{1,2}$, Teruo Miyata ${ }^{2}$ and Takahiro Ochiya*1
}

Address: ${ }^{1}$ Section for Studies on Metastasis, National Cancer Center Research Institute, Tokyo, Japan and ${ }^{2}$ Koken Bioscience Institute, Koken Co., Ltd., Tokyo, Japan

Email: Kimi Honma - khonma@kokenmpc.co.jp; Teruo Miyata - tmiyata@kokenmpc.co.jp; Takahiro Ochiya* - tochiya@ncc.go.jp

* Corresponding author

Published: 20 June 2007

Cancer Cell International 2007, 7:12 doi:10.1 186/1475-2867-7-12

This article is available from: http://www.cancerci.com/content/7/1/12

(c) 2007 Honma et al; licensee BioMed Central Ltd.

This is an Open Access article distributed under the terms of the Creative Commons Attribution License (http://creativecommons.org/licenses/by/2.0), which permits unrestricted use, distribution, and reproduction in any medium, provided the original work is properly cited.
Received: 27 April 2007

Accepted: 20 June 2007

\begin{abstract}
Background: Invasion is a hallmark of a malignant tumor, such as a glioma, and the progression is followed by the interaction of tumor cells with an extracellular matrix (ECM). This study examined the role of type I collagen in the invasion of the malignant human glioma cell line T98G by the introduction of the human collagen type I $\alpha$ I (HCOLIAI) gene.

Results: The cells overexpressing HCOLIAI were in a cluster, whereas the control cells were scattered. Overexpression of HCOLIAI significantly suppressed the motility and invasion of the tumor cells. The glioma cell growth was markedly inhibited in vitro and in vivo by the overexpression of HCOLIAI; in particular, tumorigenicity completely regressed in nude mice. Furthermore, the HCOLIAI gene induced apoptosis in glioma cells.

Conclusion: These results indicate that HCOLIAI have a suppressive biological function in glioma progression and that the introduction of HCOLIAI provides the basis of a novel therapeutic approach for the treatment of malignant human glioma.
\end{abstract}

\section{Background}

The processes of tumor cell invasion into the stromal tissue are closely related to the interactions between tumor cells and extracellular matrix (ECM). Furthermore, the alteration of the expression and modification of ECM proteins in tumor cells is relevant to their invasiveness into surrounding normal tissue. For example, loss of fibronectin, which is an ECM glycoprotein from the cell surface, has been indicated to be closely associated with malignant transformation of cells [1]. It was then shown that the overexpression of fibronectin in human fibrosarcoma cells was able to suppress the motility and growth potential of tumor cells [1]. Collagens are the most important components of ECM and play an important role in cell adhesion, movement, differentiation, proliferation, and metastasis of tumor cells. Recently, fragments of type IV, type $\mathrm{XV}$, and type XVIII collagen, which are components of various basement membranes, have been extensively studied for their potential in the reduction of angiogenesis and tumorigenesis $[2,3]$. Endostatin, a non-collagenous C-terminal domain (NC1) fragment of type XVIII collagen, was the first endogenous fragment characterized with anti-angiogenic properties [4]. The NC1 fragments of type $\mathrm{XV}$ collagen and type IV collagen were also identified as an endogenous angiogenesis inhibitor [5-11].

Type I collagen is a fibrillar collagen that consists of two polypeptide chains, the $\alpha 1$ (I) chain and the $\alpha 2$ (I) chain. 
Most of type I collagen molecules are distributed as heterotrimers $[\alpha 1(\mathrm{I})]_{2} \alpha 2(\mathrm{I})$, and a small number of molecules exist as homotrimers $[\alpha 1(\mathrm{I})]_{3}$. Although type I collagen is the most abundant collagen in skin, bone, and other tissues and organs, no type I collagen molecule and/or fragments have been demonstrated to have suppressive efficacy on malignant phenotypes of a tumor. However, variations in the production of type I collagen by tumors have been reported in the relationship with tumor progression, and transformed cells generally synthesize less collagen than their counterparts [12-15]. The differential expression between hepatocellular carcinomas and normal liver was revealed, and type I collagen was down-regulated in hepatocellular carcinomas [15]. In a neuroblastoma, type I collagen biosynthesis is a helpful marker for studying specific patterns of transdifferentiation associated with the loss of malignant potential [16]. In addition, type I collagen was able to inhibit growth and malignant transformation in human glioma cells $[17,18]$. In the present study, a type I collagen gene was introduced to glioma, which is characterized by marked tumor cell proliferation and extensive local invasion, in order to examine the inhibitory effects of the overexpressed HCOL1A1 on invasion and tumorigenesis. The results showed that overexpression of HCOL1A1 in malignant glioma cells suppressed cell proliferation, inhibited cell motility and invasiveness, and arrested tumor formation in vivo.

\section{Results \\ Overexpression of HCOLIAI in T98G cells}

Human type I collagen cDNA (HCOL1A1) was transfected into the human malignant glioma cell line T98G. Twentynine colonies of G418-resistant cells were cloned, and G418-resistant clones were screened for expression of HCOL1A1 by immuno-detection with a polyclonal anti$\alpha 1$ (I) collagen antibody. Two independent clones stably over-expressing HCOL1A1, designated HOCL1A1-I and HCOL1A1-II, were isolated. By immunocytochemical staining HCOL1A1-I and HCOL1A1-II cells showed strong immunoreactivity, while HCOL1A1 peptides were not detectable in wild cells and Mock cells (Fig. 1a). Expression of HCOL1A1 peptides were also confirmed in the whole cell lysates and the conditioned medium from HCOL1A1-transfected cells by immunoblot analysis. Although immunoreactive protein bands, which are absent in parental wild cells and Mock-transfected cells, were clearly identified, HCOL1A1 peptides were digested into fragments and did not fold into triple helices characteristic of type I collagen (data not shown).

The cell densities of the HCOL1A1-transfected cells (4 days) were significantly different from that of wild cells and Mock cells (Fig. 1b): this was clearly shown that the growth inhibition of HCOL1A1-transfected cells, as well as they were tightly cell-cell contacted in clusters, while control cells were dispersed and spindle-shaped in scatter-

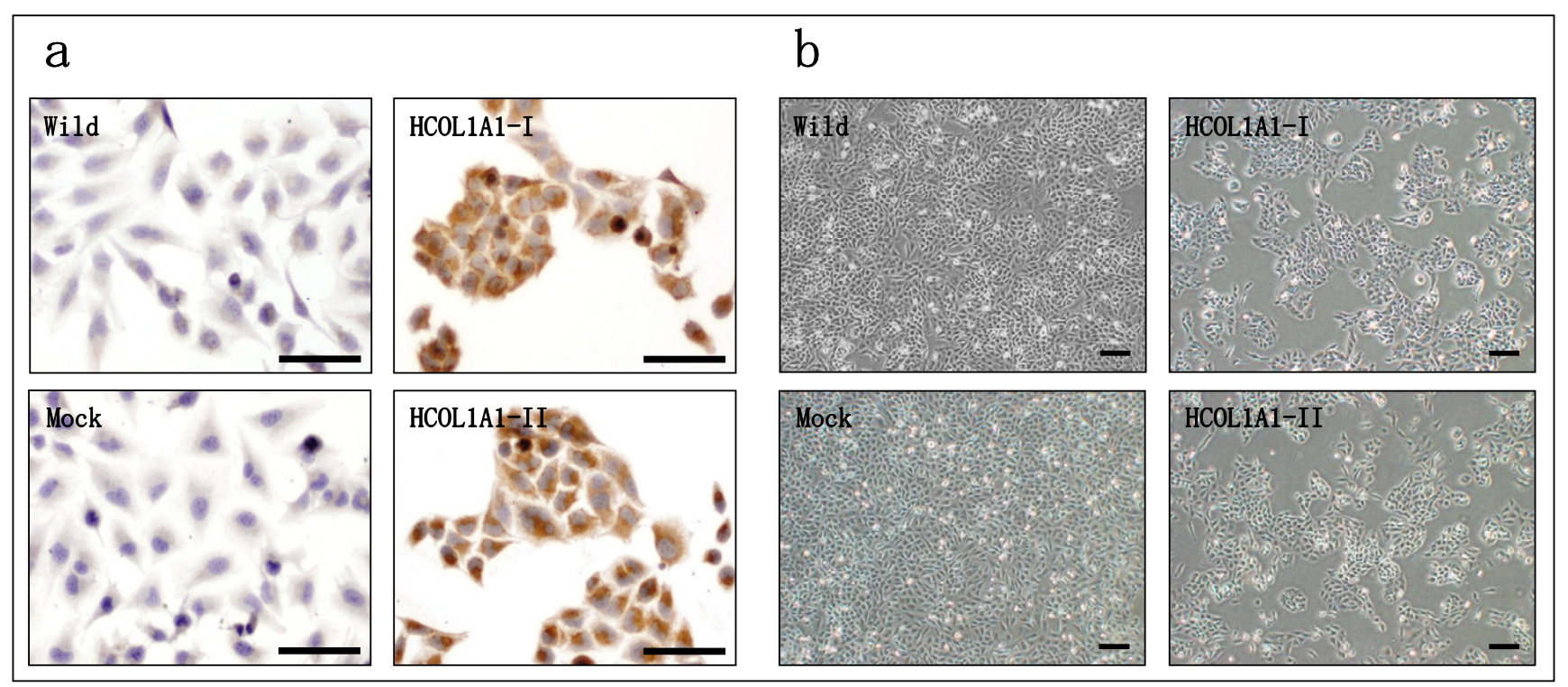

\section{Figure I}

Morphological changes of the HCOLIAI-overexpressing T98G cells. Wild cells (Wild), control transfected cells (Mock), and HCOLIAI-transfected cells (HCOLIAI-I and HCOLI-II) were seeded at I $\times 10^{5}$ cells on 6-cm culture dishes and grown for 2 to 4 days. (a) Immunocytochemical staining of T98G cells (day 2). HCOLIAI peptides were immunostained with polyclonal anti- $\alpha$ I (I) collagen antibody. Scale bar: $100 \mu \mathrm{m}$. (b) Phase-contrast photomicrographs of T98G cells (day 4). Scale bar: $200 \mu \mathrm{m}$. 
ing as usual (Fig. 1a). These results suggest that forced expression of HCOL1A1 resulted in apparent cell density changes in T98G cells.

\section{Inhibition of cell growth by HCOLIAI}

The effect of HCOL1A1 expression on the growth of T98G cells was further evaluated kinetically (Fig. 2). Cell growth was significantly suppressed in HCOL1A1-I and HCOL1A1-II cells, $P<0.001$ and $P<0.0001$ versus Mock cells, respectively. These results showed that overexpression of HCOL1A1 was able to inhibit the growth of T98G cells in vitro.

\section{Suppression of tumor cell motility and invasion by HCOLIAI}

Whether the HCOL1A1 peptide inhibits tumor cell motility was examined. (Fig. 3a, 3b). The motility of HCOL1A1-transfected cells was dramatically lower than that of Mock cells. The migration of HCOL1A1-I and HCOL1A1-II cells was inhibited more than $80 \%$ as compared to Mock cells.

Furthermore, the effect of HCOL1A1 overexpression on the invasiveness of T98G cells was assessed. Figure 3c and $3 \mathrm{~d}$ shows the ability of these cells to invade through the reconstituted Matrigel ECM. HCOL1A1-transfected cells displayed a significant reduction in invasion of more than $55 \%$.

In the in vitro invasion model using reconstituted basement membrane wafers, HCOL1A1-I cells hardly invaded the Matrigel wafer on day 7 (Fig. 3e). In contrast, a number of Mock cells invaded the Matrigel wafer. Thus, it

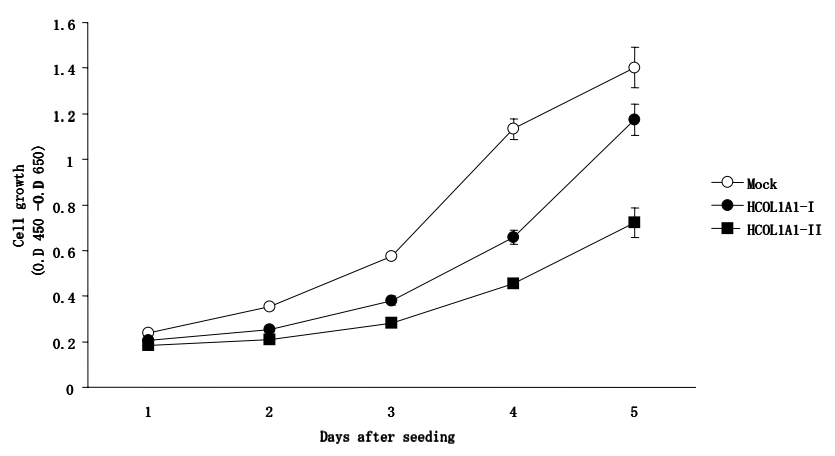

Figure 2

Inhibition of T98G cell growth in vitro by HCOLIAI expression. The graph shows the growth curves of Mock cells (Mock, O) and HCOLIAI-transfected cells (HCOLIAI-I, ; HCOLIAI-II, $\mathbf{0})$. The same number of cells were seeded and cultured for 5 days. At each time point, the cells were assayed for proliferation. Each value represents mean \pm SD $(n=8)$. was clearly demonstrated that the HCOL1A1 peptide suppressed the cell motility and invasion of T98G cells.

\section{Inhibition of tumor formation in vivo by HCOLIAI}

To assess the effects of forced HCOL1A1 expression on T98G glioma cell growth in vivo, HCOL1A1-I cells and Mock cells were injected into nude mice s.c., and the tumor volumes were determined 87 days later (Fig. 4). Figure $4 \mathrm{~b}$ shows that HCOL1A1-I cells had grown more poorly and formed smaller nodules than the Mock cells. At 87 days, the animals were sacrificed, and complete tumor regression was observed in the mice transplanted with HCOL1A1-I cells. In contrast, the control cell-transplanted animals had developed large tumors of around $1,000 \mathrm{~mm}^{3}$. These results suggest that the introduction of HCOL1A1 was able to function as a growth suppressor in human glioma cells in vivo.

\section{Induction of apoptotic cells in vitro by HCOLIAI}

The effect of overexpressed HCOL1A1 on the apoptosis of glioma was studied by the TUNEL assay (Fig. 5). Figure 5a shows that numerous apoptotic cells were detected in HCOL1A1-transfected cells, whereas apoptotic cells were scarcely seen in the Mock cells. The number of apoptotic cells was counted in the microscopic fields, and the percentage of apoptotic cells is revealed in Figure 5b. The apoptosis rates of HCOL1A1-I and HCOL1A1-II were $17 \%$ and $29 \%$, respectively. In contrast, Mock cells showed less than $1 \%$ of apoptotic cells. Therefore, the over-expression of HCOL1A1 induced the apoptosis of T98G glioma cells and this may partially contribute to the growth suppression of HCOL1A1 tumors in mice.

\section{Discussion}

The present study shows that the overexpression of HCOL1A1 in T98G malignant glioma cells markedly changed the cell morphology and significantly suppressed the motility and invasion of cells. In addition, the inhibition of glioma cell growth was indicated in vitro and in vivo; in particular, tumorigenicity had regressed completely in nude mice. Moreover, HCOL1A1 induced the apoptosis of glioma cells, and this finding suggested that apoptosis participates in a mechanism for the suppression of malignancy of T98G glioma cells by forced expression of HCOL1A1. Interestingly, overexpression of HCOL1A1 in 293 cells, which are transformed human embryo kidney cell line and do not express HCOL1A1, showed no influence on the cell morphology, growth and apoptosis induction (data not shown). This finding suggests that ectopic forced expression of HCOL1A1 protein in cells dose not cause of unfolded protein response which induces apoptosis, however, the effects of accumulation of unfolded HCOL1A1 protein on various cell types should be further considered. 


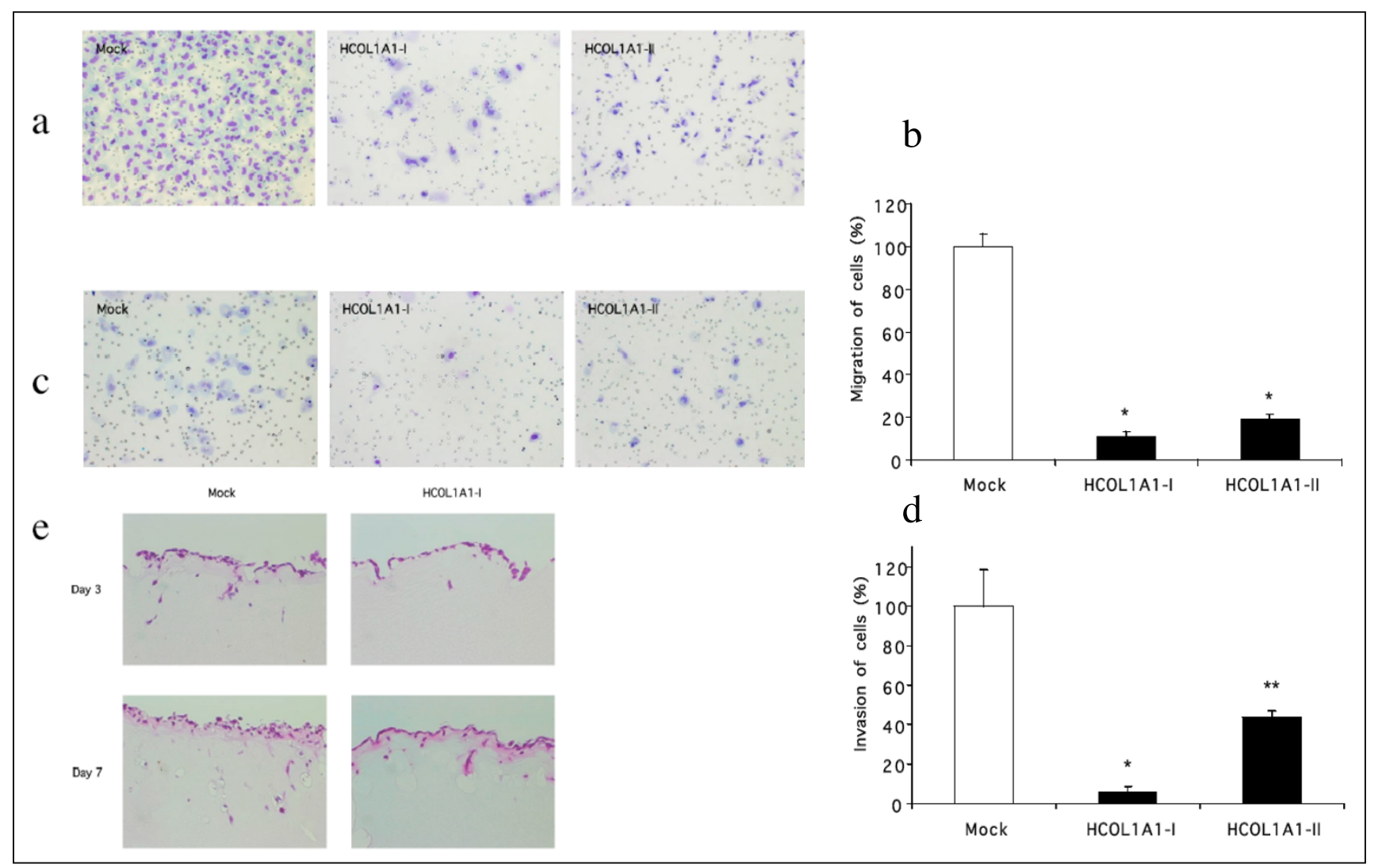

Figure 3

Suppression of T98G cell motility and invasion by overexpression of HCOLIAI. Mock cells (Mock) and HCOLIAI-transfected cells (HCOLIAI-I and HCOLIAI-II) were added to a transwell chamber and the cell motility was evaluated. (a) The migrated cells were stained and photographed under the microscope at $\times 100$ magnification. (b) The number of migrated cells was counted, and the results represent a percentage of Mock cells. Each value is a mean $\pm \operatorname{SD}(n=4)$. *, $P<0.00 \mathrm{I}$, when tested against the Mock. Mock cells (Mock) and HCOLIAI-transfected cells (HCOLIAI-I and HCOLIAI-II) were added to a transwell chamber coated with Matrigel and the cell invasion was evaluated. (c) The invaded cells were stained and photographed under a microscope at $\times 100$ magnification. (d) The number of invaded cells was counted, and the results are expressed as a percentage of Mock cells. Each value is a mean $\pm \operatorname{SD}(n=4)$. $, P<0.00 \mathrm{I}, * *, P<0.0 \mathrm{I}$ when tested against the Mock. The cell invasion into an in vitro invasion model was evaluated using reconstituted basement membrane wafers. (e) Mock cells (Mock) and HCOLIAI-transfected cells (HCOLIAI-I) were plated onto Matrigel wafers. On days 3 and 7 after plating, Matrigel wafers and adherent cells were fixed, and sections were stained with hematoxylin and eosin. Magnification, $\times 200$.

It has been pointed out that loss of ECM control is a characteristic feature in malignant tumor progression toward invasion [19]. In glioma cells, the expression of ECM components, such as decorin, tenascin, vitronectin, laminin, fibronectin, type I collagen, type IV collagen, neuronal cell adhesion molecule (NCAM), N-cadherin, and beta-catenin, dramatically changes during tumor progression, and these ECM proteins have been reported to play a significant role in the migration and invasion of gliomas $[18,20-$ 29]. As an example of glioma therapy using ECM protein, decorin, which is poorly expressed by glioma cell lines, was ectopically expressed in glioma cells and successfully used to abrogate the growth of experimental gliomas
$[20,30,31]$. Similarly, the overexpression of type I collagen should be useful for suppression of glioma progress.

It has become clear that ECM proteins have unknown physiological cell functions. Recently, the biological functions of various collagen fragments have been described; fragments of type IV, type XV, and type XVIII collagen have been noted for their potential $[2,3]$. Type IV, type XV, and type XVIII collagen are major components of various basement membranes. Although their functional role in basement membrane architecture is well known, the NC1 fragments of these collagens are involved in the regulatory functions of various cellular events, such as angiogenesis, 

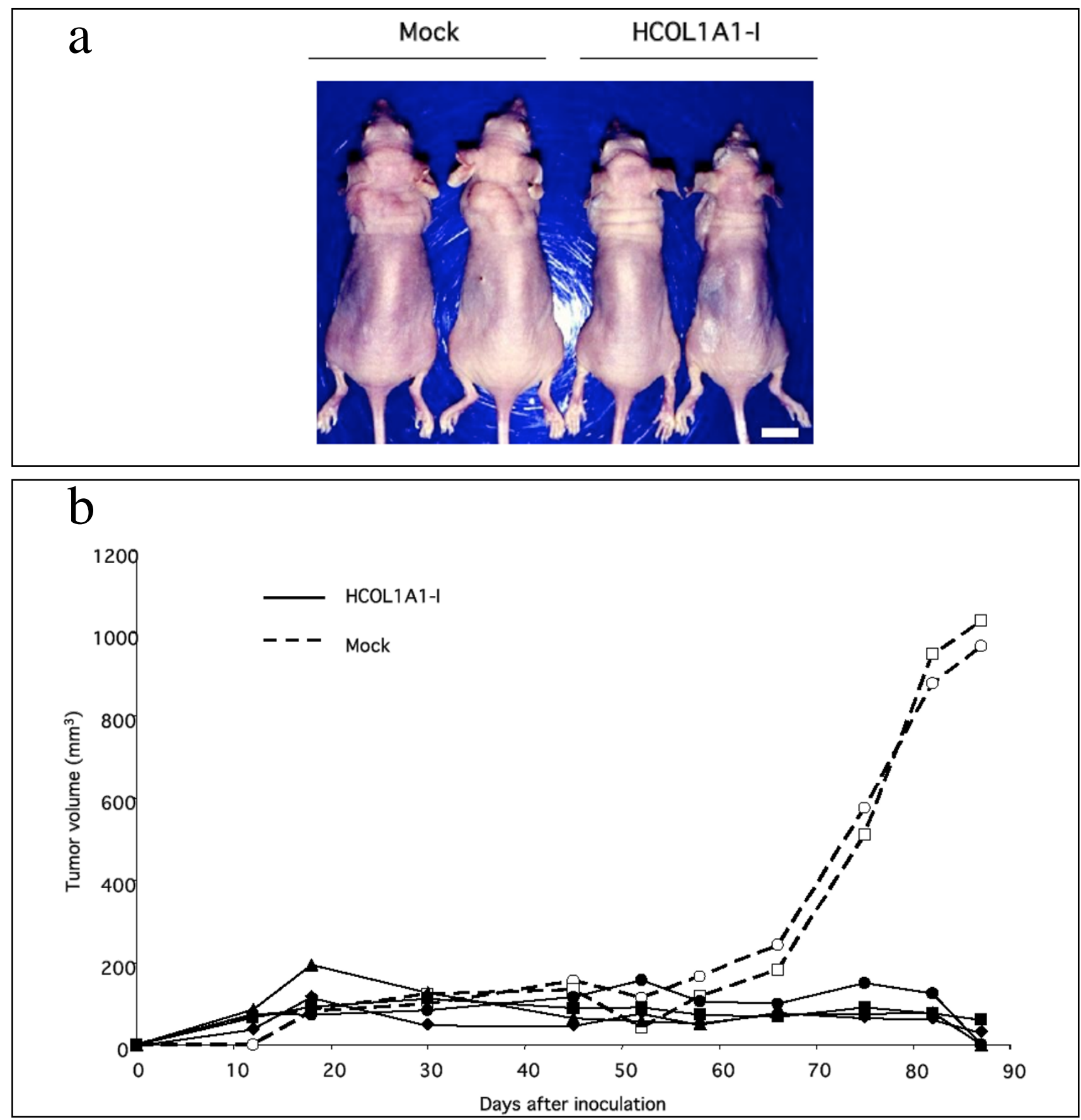

\section{Figure 4}

Inhibition of tumor formation of T98G cells in vivo by introduction of the HCOLIAI gene. T98G cells were implanted s.c in the forelegs of nude mice, and the tumor volume was measured at each time point. (a) Tumor formation in nude mice at 87 days after inoculation with Mock cells (Mock) or HCOLIAI-transfected cells (HCOLIAI-I). Scale bar, I cm. (b) The in vivo tumor growth of HCOLIAI-transfected cells (HCOLIAI-I, $n=4)$ was compared with that of Mock cells (Mock, $n=2)$. 


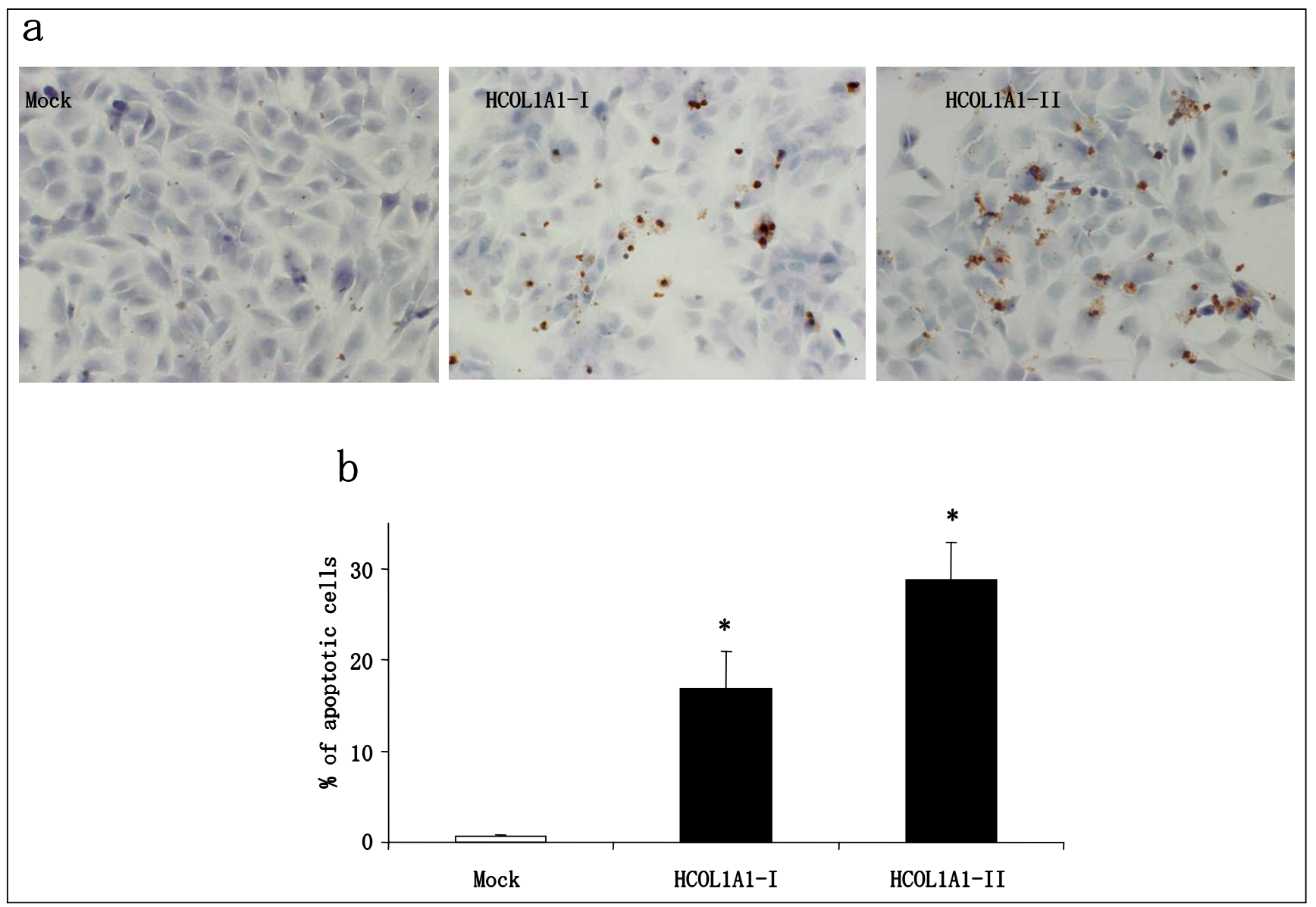

\section{Figure 5}

Induction of apoptotic T98G cells in vitro by overexpression of HCOLIAI. Mock cells (Mock) and HCOLIAI-transfected cells (HCOLIAI-I and HCOLIAI-II) were assayed for apoptosis using the in situ TUNEL method. (a) The photomicrographs of Apoptotic cells. Magnification, $\times 200$. (b) The percentage of apoptotic cells represents the mean \pm SD ( $n=5$, duplicate experiment). *, $P<0.00$ I, when tested against the Mock.

tumorigenesis, migration, proliferation, apoptosis, and morphogenesis, which are distinct from those of original intact molecules [2-11,32-36]. Endostatin, which is an NC1 fragment of type XVIII collagen, has been extensively studied in the angiogenesis field $[4,37,38]$. It has been reported that endostatin inhibits tumor cell invasion, as well as HCOL1A1 peptides, which were presented here. Endostatin inhibits tumor cell invasion by blocking the activation of latent matrix metalloprotease-2, -9, and -13 [39-41]. However, in this study, there was no difference in the level of activated MMP-2 and MMP-9 between HCOL1A1-transfected cells and Mock cells by gelatin zymography analysis (data not shown). This finding suggests that the HCOL1A1 peptide may have a unique function as a suppressor of tumor cell invasion that is distinct from that of NC1 fragments of basement membrane collagens. It was demonstrated that endostatin suppresses cell proliferation in vitro and inhibits the growth of primary tumors and metastases by induction of apoptosis [42-44]. Similarly, the expression of HCOL1A1 peptides caused inhibition of tumor cell growth in vitro and complete regression of tumors in nude mice. Moreover, HCOL1A1 peptides induced apoptosis in glioma cells. Thus, HCOL1A1 peptides, as well as endostatin and other NC1 fragments of collagens, should also have a potential for anti-tumorigenesis. Interestingly, type I collagen is a fibrillar collagen, whereas fragments of collagens, which have so far been reported to inhibit tumor progression, are derived from basement membrane collagens. The HCOL1A1 peptides, which are derived from fibrillar collagen, may be novel inhibitors of tumor growth and invasion. In this report, the mechanism for the suppression of malignancy of T98G glioma is not evident, but it should become clear with further study. 
Recently, significant technical advances in the treatment of gliomas have emerged, and gene therapy, in particular, is noted as a potent therapeutic strategy. The major approaches of gene therapy to glioma are based on apoptosis-related gene therapy [45], antiangiogenesis therapy $[46,47]$, and immunotherapy $[48,49]$. Several ECM components and their fragments, such as decorin [20,30,31] and endostatin $[46,50-54]$ are being tried as potential targets for glioma gene therapy. The HCOL1A1 gene may also be a good candidate as gene medicine for a novel therapy against glioma.

\section{Conclusion}

In summary, the tumor growth and invasion of malignant human gliomas were markedly suppressed by the introduction of HCOL1A1. The suppression of a malignant phenotype of glioma cells by HCOL1A1 provides the basis of a novel therapeutic approach.

\section{Materials and methods \\ Cell culture}

The human glioma T98G cells were derived from glioblastoma and obtained from the American Type Culture Collection. Cells were maintained and passaged in a minimum essential medium (MEM) supplemented with $10 \%$ fetal bovine serum (FBS), $1 \%$ nonessential amino acids, and $1 \mathrm{mM}$ sodium pyruvate at $37^{\circ} \mathrm{C}$.

\section{HCOLIAI expression plasmid}

An $\alpha 1$ chain of the human type I procollagen expression vector, pCXN2/HCOL1A1, was constructed as follows. The cDNA of HCOL1A1 was cloned from a human heart cDNA library, and a partial cDNA fragment was synthesized by RT-PCR using mRNA of a normal human skin fibroblast. cDNA encoding the full-length HCOL1A1 gene was assembled from these fragments. The full-length HOCL1A1 CDNA was cloned into the downstream of the CAG promoter of a pCXN2 expression vector containing the neomycin resistance gene.

\section{Cell transfection}

Cells were transfected with pCXN2/HCOL1A1 or pCXN2 without an insert, as a Mock, by using LipofectAMINE 2000 (Invitrogen Corporation, CA) according to the manufacturer's protocol. Cells were selected in a medium containing $0.8 \mathrm{mg} / \mathrm{ml}$ of G418. G418-resistant colonies were cloned and expanded.

\section{Immunocytochemical staining}

T98G cells $\left(1 \times 10^{5}\right)$ were grown for 2 to 4 days on $6-\mathrm{cm}$ culture dishes and fixed with cold methanol at $-20^{\circ} \mathrm{C}$ for $5 \mathrm{~min}$. The cells were permeated with $0.02 \%$ Triton X-100 in PBS for $15 \mathrm{~min}$ and pretreated with $3 \% \mathrm{H}_{2} \mathrm{O}_{2}$ in methanol for 15 min to quench endogenous peroxidase activity. The cells were blocked with Block Ace (Dainippon
Pharmaceutical Co., Ltd., Osaka, Japan) overnight at $4{ }^{\circ} \mathrm{C}$ and incubated with polyclonal anti- $\alpha 1(\mathrm{I})$ collagen antibody (L-19) (1:60) (Santa Cruz Biotechnology, Inc., CA) at $37^{\circ} \mathrm{C}$ for $1 \mathrm{~h}$. Bound primary antibodies were labeled with biotinylated IgG antibodies (1:500) (Santa Cruz Biotechnology, Inc., CA) at $37^{\circ} \mathrm{C}$ for $15 \mathrm{~min}$ and incubated with streptavidin-peroxidase at $37^{\circ} \mathrm{C}$ for $20 \mathrm{~min}$. HCOL1A1 peptides were visualized with diaminobenzidine, and nuclei were counterstained with hematoxylin.

\section{In vitro growth assay}

Individual clones were seeded in 96-well plates at a density of $5 \times 10^{2}$ cells per well in $100 \mu$ l of a culture medium. At each time point, the cells were assayed for proliferation with TetraColor One, a cell-proliferation assay reagent (Seikagaku Co., Tokyo, Japan), according to the recommended method; they were then measured for absorbency at the well at $450 \mathrm{~nm}$ with a reference wavelength at $650 \mathrm{~nm}$.

\section{In vitro invasion and motility assay}

In vitro invasion assays were performed using a Matrigel invasion chamber $(8-\mu \mathrm{m}$ pore size, Becton Dickinson, Bedford, MA). A suspension of $2.5 \times 10^{4}$ cells in $0.5 \mathrm{ml}$ of a serum free medium, Cosmedium 001, was added to the Matrigel chamber. The chambers were incubated at $37^{\circ} \mathrm{C}$ for $24 \mathrm{~h}$ in a $95 \%$ air $/ 5 \% \mathrm{CO}_{2}$ incubator. The cells on the lower surface of the membrane were stained with DiffQuik stain (Kokusaisiyaku, Kobe, Japan). The invadin cells were photographed under a microscope at $\times 100$ magnification and counted in five fields of four membranes.

A cell motility assay was performed in a similar manner except that the $8-\mu \mathrm{m}$ pore size PET membrane was not coated with Matrigel.

\section{Tumor invasion into a matrigel wafer}

The reconstituted basement membrane wafers were made by adding $1 \mathrm{ml}$ of Growth Factor Reduced Matrigel (Becton Dickinson, MA) to a well of a 24-well plate and gelled at $37^{\circ} \mathrm{C}$ for $30 \mathrm{~min} .1 \times 10^{5}$ cells were plated onto the surface of each wafer. On days 3 and 7 after plating, Matrigel wafers and adherent cells were fixed with $4 \%$ paraformaldehyde in PBS for $1 \mathrm{~h}$. The wafers were then dehydrated through a graded ethanol series and embedded in paraffin. Sections were cut and stained with hematoxylin and eosin.

\section{In vivo tumor formation}

T98G cells $\left(4.3 \times 10^{6}\right)$ were implanted subcutaneously in $100 \mu \mathrm{l}$ of a 1:1 mixture of a culture medium and Growth Factor Reduced Matrigel in the forelegs of the nude mice according to the method described by Rubenstein et al. [55] and Teicher et al. [56]. The tumor volume was meas- 
ured with a caliper and calculated using the formula width $^{2} \times$ length $\times 0.5$. Animal experiments in the present study were performed in compliance with the guidelines of the Institute for Laboratory Animal Research, National Cancer Center Research Institute.

\section{Apoptosis assay}

In the normal growth medium, $1.8 \times 10^{5}$ cells were seeded onto $6-\mathrm{cm}$ culture dishes. After $24 \mathrm{~h}$, the cells were rinsed and cultured in a serum-free medium, Cosmedium 001, which contained no protein except insulin and transferrin and was supplemented with sodium ascorbate $(50 \mu \mathrm{g} / \mathrm{ml})$ to avoid the effects of several ECM proteins carried by the serum. Five days later, the cells were assayed for apoptosis by the TUNEL method with the In Situ Cell Death Detection Kit, POD (Roche, Switzerland) according to the manufacturer's instructions. Apoptotic cells were identified by diaminobenzidine staining, and nuclei were counterstained with hematoxylin. The number of apoptotic cells was counted in five microscopic fields.

\section{Statistical analysis}

The results are given as means \pm SD. Student's t-test was performed for statistical evaluation, with $P<0.05$ considered significant.

\section{Abbreviations}

ECM, extracellular matrix; HCOL1A1, human collagen type I $\alpha 1$.

\section{Authors' contributions}

$\mathrm{KH}$ carried out most of experiments. KH, TM and TO participated in its design and helped to the draft the manuscript. All authors read and approved the final manuscript.

\section{Acknowledgements}

We are grateful to Dr Masaaki Terada and Dr Hisae Hori for their participation in helpful discussions and to Dr Junichi Miyazaki of Osaka University, Osaka, Japan, for the kind gift of the CAG promoter. We also thank Ms Masako Hosoda, Mr Jun Onodera and Mr Kazuki Nemoto for their excellent technical work. This work was supported in part by Grants-in-Aid for the Second- and Third-Term Comprehensive 10-Year Strategy for Cancer Control, Health Science Research Grants for the Research on the Human Genome and Gene Therapy from the Ministry of Health, Labour and Welfare of Japan, a Grant-in-aid for Scientific Research on Priority Areas of the Ministry of Education, Culture, Sports, Science and Technology.

\section{References}

I. Akamatsu $\mathrm{H}$, Ichihara-Tanaka K, Ozono K, Kamiike W, Matsuda $\mathrm{H}$, Sekiguchi K: Suppression of transformed phenotypes of human fibrosarcoma cells by overexpression of recombinant fibronectin. Cancer Res 1996, 56:454I-4546.

2. Ortega N, Werb Z: New functional roles for non-collagenaous domains of basement membrane collages. J Cell Sci 2002 I I 5:420I-4204.

3. Clamp AR, Jayson GC: The clinical potential of antiangiogenic fragments of extracellular matrix proteins. $\mathrm{Br}$ / Cancer 2005 93:967-972.
4. O'Reilly MS, Boehm T, Shing Y, Fukai N, Vasios G, Lane WS, Flynn E, Birkhead JR, Olsen BR, Folkman J: Endostatin: an endogenous inhibitor of angiogenesis and tumor growth. Cell 1997, 88:277-285.

5. Ramchandran R, Dhanabal M, Volk R, Waterman MJF, Segal M, Lu H, Knebelmann B, Sukhatme VP: Antiangiogenic activity of restin, NCIO domain of human collagen XV: comparison to endostatin. Biochem Biophys Res Commun 1999, 255:735-739.

6. Sasaki T, Larsson H, Tisi D, Claesson-Welsh L, Hohenester E, Timpl $R$ : Endostatins derived from collagens XV and XVIII differ in structural and binding properties, tissue distribution and anti-angiogenic activity. I Mol Biol 2000, 30 I: I I79-II 90.

7. Colorado PC, Torre A, Kamphaus G, Maeshima Y, Hopfer H, Takahashi K, Volk R, Zamborsky ED, Herman S, Sarkar PK: Anti-angiogenic cues from vascular basement membrane collagen. Cancer Res 2000, 60:2520-2526.

8. Kamphaus GD, Colorado PC, Panka DJ, Hopfer H, Ramchandran R, Torre A, Maeshima Y, Mier JW, Sukhatme VP, Kalluri R: Canstatin, a novel matrix-derived inhibitor of angiogenesis and tumor growth. I Biol Chem 2000, 275: I 209-I2I5.

9. Maeshima Y, Manfredi M, Reimer C, Holthaus KA, Hopfer H, Chandamuri BR, Kharbanda S, Kalluri R: Identification of the anti-angiogenic site within vascular basement membrane-derived tumstatin. J Biol Chem 200I, 276: I5240-I5248.

10. Hamano $\mathrm{Y}$, Kalluri R: Tumstatin, the $\mathrm{NCI}$ domain of alpha3 chain of type IV collagen, is an endogenous inhibitor of pathological angiogenesis and suppresses tumor growth. Biochem Biophys Res Commun 2005, 333:292-298.

II. Lima E, Silva R, Kachi S, Akiyama H, Shen J, Aslam S, Yuan Gong Y, Khu NH, Hatara MC, Boutaud A, Peterson R, Campochiaro PA: Recombinant non-collagenous domain of alpha2(IV) collagen causes involution of choroidal neovascularization by inducing apoptosis. J Cell Physiol 2006, 208:16I-I66.

12. Adams S, Sobel ME, Howard B, Olden K, Yamada KM, de Crombrugghe $B$, Pastn I: Levels of translatable mRNAs for cell surface protein, collagen precursors, and two membrane proteins are altered in Rous sarcoma virus-transformed chick embryo fibroblasts. Proc Natl Acad Sci USA 1977, 74:3399-3403.

13. Sandmeyer $S$, Bornstein $P$ : Declining procollagen mRNA sequence in chick embryo fibroblast infected with Rous sarcoma virus. J Biol Chem 1979, 254:4950-4953.

14. Vaheri A, Kirkinen M, Lehto VP, Linder E, Timpl R: Codistribution of pericellular matrix proteins in cultured fibroblasts and loss of transfomation: fibronectin and procollagen. Proc Nat Acad Sci USA 1976, 75:4944-4948.

15. Tannapfel A, Anhalt K, Hausermann P, Sommerer F, Benicke M, Uhlmann D, Witzigmann $H$, Hauss J, Wittekind C: Identification of novel proteins associated with hepatocellular carcinomas using protein microarrays. J Pathol 2003, $201: 238-249$.

16. DeClerck YA, Bomann ET, Spengler BA, Biedler JL: Differential collagen biosynthesis by human neuroblastoma cell variants. Cancer Res 1987, 47:6505-6510.

17. Rutka JT, Giblin JR, Apodaca G, DeArmond SJ, Stern R, Rosenblum $M L$ : Inhibition of growth and induction of differentiation in a malignant human glioma cell line by normal leptomeningeal extracellular matrix proteins. Cancer Res 1987, 47:35I5-3522.

18. Savaraj N, Wu C, Landy H, Wangpaijit M, Wei Y, Kuo MT, Robles C, Furst AJ, Lampidis T, Feun L: Procollagen alpha I type I: a potential aide in histopathological grading of glioma. Cancer Invest 2005, 23:577-58I

19. Tysnes BB, Mahesparan R: Biological mechanisms of glioma invasion and potential therapeutic targets. J Neurooncol 200I, 53:129-147.

20. Stander M, Naumann U, Dumitrescu L, Heneka M, Loschmann P, Gulbins E, Dichgans J, Weller M: Decorin gene transfer-mediated suppression of TGF-beta synthesis abrogates experimental malignant glioma growth in vivo. Gene Ther 1998, 5:1 187-I| 94.

21. Bouterfa H, Darlapp AR, Klein E, Pietsch T, Roosen K, Tonn JC: Expression of different extracellular matrix components in human brain tumor and melanoma cells in respect to variant culture conditions. J Neurooncol 1999, 44:23-33.

22. Mahesparan R, Read TA, Lund-Johansen M, Skaftnesmo KO, Bjerkvis $R$, Engebraaten $O$ : Expression of extracellular matrix components in a highly infiltrative in vivo glioma model. Acta Neuropathol (Berl) 2003, 105:49-57. 
23. Khazenzon NM, Ljubimov AV, Lakhter AJ, Fujita M, Fujiwara $H$, Sekiguchi K, Sorokin LM, Petajaniemi N, Virtanen I, Black KL, Ljubimova JY: Antisense inhibition of laminin-8 expression reduces invasion of human gliomas in vitro. Mol Cancer Ther 2003, 2:985-994

24. Hikawa T, Mori T, Abe T, Hori S: The ability in adhesion and invasion of drug-resistant human glioma cells. J Exp Clin Cancer Res 2000, 19:357-362.

25. Tews DS: Adhesive and invasive features in gliomas. Pathol Res Pract 2000, 196:701-7II.

26. Utsuki S, Sato Y, Oka H, Tsuchiya B, Suzuki S, Fujii K: Relationship between the expression of $\mathrm{E}-, \mathbf{N}$-cadherins and beta-catenin and tumor grade in astrocytomas. J Neurooncol 2002, 57:187-192.

27. Asano K, Kubo O, Tajika Y, Huang MC, Takakura K, Ebina K, Suzuki $\mathrm{S}$ : Expression and role of cadherins in astrocytic tumors. Brain Tumor Pathol 1997, 14:27-33.

28. Shinoura N, Paradies NE, Warnick RE, Chen H, Larson JJ, Tew J], Simon M, Lynch RA, Kanai Y, Hirohashi S: Expression of $\mathbf{N}$-cadherin and alpha-catenin in astrocytomas and glioblastomas. $\mathrm{Br}$ J Cancer 1995, 72:627-33.

29. Asano K, Duntsch CD, Zhou Q, Weimar JD, Bordelon D, Robertson $\mathrm{J}$, Pourmotabbed $\mathrm{T}$ : Correlation of $\mathbf{N}$-cadherin expression in high grade gliomas with tissue invasion. J Neurooncol 2004, 70:3-15.

30. Munz C, Naumann U, Grimmel C, Rammensee HG, Weller M: TGFbeta-independent induction of immunogenicity by decorin gene transfer in human malignant glioma cells. Eur J Immunol 1999, 29: 1032-1040.

31. Engel S, Isenmann S, Stander M, Rieger J, Bahr M, Weller M: Inhibition of experimental rat glioma growth by decorin gene transfer is associated with decreased microglial infiltration. J Neuroimmunol 1999, 99:13-18.

32. Roth JM, Akalu A, Zelmanovich A, Policarpio D, Ng B, MacDonald S, Formenti S, Liebes L, Brooks PC: Recombinant alpha2(IV)NCI domain inhibits tumor cell-extracellular matrix interactions, induces cellular senescence, and inhibits tumor growth in vivo. Am J Pathol 2005, I 66:901-911.

33. He GA, Luo JX, Zhang TY, Wang FY, Li RF: Canstatin-N fragment inhibits in vitro endothelial cell proliferation and suppresses in vivo tumor growth. Biochem Biophys Res Commun 2003, 3 I 2:801-805.

34. He GA, Luo JX, Zhang TY, Hu ZS, Wang FY: The C-terminal domain of canstatin suppresses in vivo tumor growth associated with proliferation of endothelial cells. Biochem Biophys Res Commun 2004, 3 I 8:354-360.

35. Panka DJ, Mier JW: Canstatin inhibits Akt activation and induces Fas-dependent apoptosis in endothelial cells. I Biol Chem 2003, 278:37632-37636.

36. Sudhakar A, Sugimoto H, Yang C, Lively J, Zeisberg M, Kalluri R: Human tumstatin and human endostatin exhibit distinct antiangiogenic activities mediated by alpha $v$ beta 3 and alpha 5 beta I integrins. Proc Natl Acad Sci USA 2003, I00:4766-477|.

37. Boehm T, Folkman J, Browder T, O'Reilly MS: Antiangiogenic therapy of experimental cancer does not induce acquired drug resistance. Nature 1997, 390:404-407.

38. Sorensen DR, Read TA, Porwol T, Olsen BR, Timpl R, Sasaki T, Iversen PO, Benestad HB, Sim BK, Bjerkvig R: Endostatin reduces vascularization, blood flow, and growth in a rat gliosarcoma. Neuro-oncol 2002, 4:1-8.

39. Kim YM, Jang JW, Lee OH, Yeon J, Choi EY, Kim KW, Lee ST, Kwon YG: Endostatin inhibits endothelial and tumor cellular invasion by blocking the activation and catalytic activity of matrix metalloproteinase. Cancer Res 2000, 60:5410-54I3.

40. Lee SJ, Jang JW, Kim YM, Lee HI, Jeon JY, Kwon YG, Lee ST: Endostatin binds to the catalytic domain of matrix metalloproteinase-2. FEBS Lett 2002, 519:|47-152.

4I. Nyberg P, Heikkila P, Sorsa T, Luostarinen J, Heljasvaara R, Stenman UH, Pihlajaniemi T, Salo T: Endostatin inhibits human tongue carcinoma cell invasion and intravasation and blocks the activation of matrix metalloprotease-2, -9, and -13 . J Biol Chem 2003, 278:22404-224II.

42. Dhanabal M, Ramchandran R, Waterman MJ, Lu H, Knebelmann B, Segal M, Sukhatme VP: Endostatin induces endothelial cell apoptosis. J Biol Chem 1999, 274: II72I-II726.
43. Yokoyama Y, Dhanabal M, Griffioen AW, Sukhatme VP, Ramakrishnan S: Synergy between angiostatin and endostatin: inhibition of ovarian cancer growth. Cancer Res 2000, 60:21 90-2196.

44. Dkhissi F, Lu H, Soria C. Opolon P, Griscelli F, Liu H, Khattar P, Misha $\mathrm{Z}$, Perricaudet $\mathrm{M}$, Li H: Endostatin exhibits a direct antitumor effect in addition to its antiangiogenic activity in colon cancer cells. Hum Gene Ther 2003, 14:997-1008.

45. Shinoura N, Hamada $\mathrm{H}$ : Gene therapy using an adenovirus vector for apoptosis-related genes is a highly effective therapeutic modality for killing glioma cells. Curr Gene Ther 2003, 3:147-I53.

46. Puduvalli VK, Sawaya R: Antiangiogenesis-therapeutic strategies and clinical implications for brain tumors. J Neurooncol 2000, 50:189-200.

47. Jansen M, de Witt Hamer PC, Witmer AN, Troost D, van Noorden CJ: Current perspectives on antiangiogenesis strategies in the treatment of malignant gliomas. Brain Res Brain Res Rev 2004, 45: 143-163.

48. De Bouard S, Guillamo JS, Christov C, Lefevre N, Brugieres P, Gola E, Devanz P, Indraccolo S, Peschanski M: Antiangiogenic therapy against experimental glioblastoma using genetically engineered cells producing interferon-alpha, angiostatin, or endostatin. Hum Gene Ther 2003, I 4:883-895.

49. Ehtesham M, Black KL, Yu JS: Recent progress in immunotherapy for malignant glioma: treatment strategies and results from clinical trials. Cancer Control 2004, I I : 192-207.

50. Peroulis I, Jonas N, Saleh M: Antiangiogenic activity of endostatin inhibits C6 glioma growth. Int J Cancer 2002, 97:839-845.

5I. Pulkkanen KJ, Laukkanen JM, Fuxe J, Kettunen MI, Rehn M, Kannasto JM, Parkkinen J, Kauppinen RA, Pettersson RF, Yla-Herttuala S: The combination of HSV-tk and endostatin gene therapy eradicates orthotopic human renal cell carcinomas in nude mice. Cancer Gene Ther 2002, 9:908-916.

52. Visted $T$, Lund-Johansen $M$ : rogress and challenges for cell encapsulation in brain tumour therapy. Expert Opin Biol Ther 2003, 3:55|-56I.

53. Ohlfest JR, Demorest ZL, Motooka Y, Vengco I, Oh S, Chen E, Scappaticci FA, Saplis RJ, Ekker SC, Low WC, Freese AB, Largaespada DA: Combinatorial antiangiogenic gene therapy by nonviral gene transfer using the sleeping beauty transposon causes tumor regression and improves survival in mice bearing intracranial human glioblastoma. Mol Ther 2005, I 2:778-788.

54. Barnett FH, Scharer-Schuksz M, Wood M, Yu X, Wagner TE, Friedlander $M$ : Intra-arterial delivery of endostatin gene to brain tumors prolongs survival and alters tumor vessel ultrastructure. Gene Ther 2004, I I: I 283-1289.

55. Rubenstein M, Shaw M, Mirochnik Y, Slobodskoy L, Glick R, Lichtor T, Chou $\mathrm{P}$, Guinan $\mathrm{P}$ : In vivo establishment of T98G human glioblastoma. Methods Find Exp Clin Pharmacol 1999, 2 I:391-393.

56. Teicher BA, Menon K, Alvarez E, Galbreath E, Shih C, Faul M: Antiangiogenic and antitumor effects of a protein kinase Cbeta inhibitor in human T98G glioblastoma multiforme xenografts. Clin Cancer Res 200I, 7:634-640.

Publish with Bio Med Central and every scientist can read your work free of charge

"BioMed Central will be the most significant development for disseminating the results of biomedical research in our lifetime. "

Sir Paul Nurse, Cancer Research UK

Your research papers will be:

- available free of charge to the entire biomedical community

- peer reviewed and published immediately upon acceptance

- cited in PubMed and archived on PubMed Central

- yours - you keep the copyright
BioMedcentral 